\title{
Acquired heparin-like anticoagulation process in a patient with multiple myeloma: a case report and literature review
}

\author{
Haorui Shen ${ }^{1,2,3}$, Chao Wu ${ }^{1,2,3}$, Lijuan Chen ${ }^{1,2,3}$, Run Zhang ${ }^{1,2,3}$ \\ ${ }^{1}$ Department of Hematology, the First Affiliated Hospital of Nanjing Medical University, Jiangsu Province Hospital, Nanjing, China; ${ }^{2}$ Key \\ Laboratory of Hematology of Nanjing Medical University, Nanjing, China; ${ }^{3}$ Collaborative Innovation Center for Cancer Personalized Medicine, \\ Nanjing, China \\ Correspondence to: Dr. Run Zhang. Department of Hematology, the First Affiliated Hospital of Nanjing Medical University, Jiangsu Province \\ Hospital, Key Laboratory of Hematology of Nanjing Medical University, Collaborative Innovation Center for Cancer Personalized Medicine, \\ Nanjing 210029, China. Email: zhangrunhost@163.com.
}

\begin{abstract}
A 48-year-old multiple myeloma patient with renal insufficiency developed sustained bleeding after vein puncture. Coagulation studies showed a prolonged activated partial thromboplastin time and thrombin time. Addition of an equal volume of normal plasma did not correct the activated partial thromboplastin time completely, while the prolonged thrombin time was corrected by protamine sulfate in vitro, which indicated the presence of heparin-like anticoagulants. In our case, both of the infusion of fresh-frozen plasma or dialysis had no significant effect on the coagulation studies or the bleeding time. The patient achieved complete remission after 2 cycles of chemotherapy (bortezomib combined with cyclophosphamide and dexamethasone), meanwhile the bleeding stopped and the abnormal coagulation studies were corrected, which suggest that myeloma cells may be a source of heparin-like anticoagulants. But the source of heparin-like anticoagulants is unclear. It is worth noting that the type of $M$ protein of our patient is $\operatorname{IgD}$ lambda light chain and lambda light chain, which is not reported in previous literatures, and the special type of $M$ protein may be the source of heparin-like anticoagulants in our patient. Heparinlike anticoagulants may lead to severe bleeding in multiple myeloma patients, so early evaluation of the coagulation function of multiple myeloma patients is clinically important for early intervention.
\end{abstract}

Keywords: Multiple myeloma (MM); heparin-like anticoagulant; thrombin time; case report

Submitted May 01, 2020. Accepted for publication Sep 12, 2020.

doi: $10.21037 /$ tcr-20-1968

View this article at: http://dx.doi.org/10.21037/tcr-20-1968

\section{Introduction}

Diverse hemostatic abnormalities have been reported in patients with multiple myeloma (MM) which predispose to bleeding and also thrombosis. Several mechanisms have been proposed to explain this phenomenon, such as inhibitors of coagulation factors, direct inhibition of fibrin monomer polymerization or presence of $M$ protein binding to von Willebrand factor (1-4). Another uncommon cause of bleeding in patients with $M M$ is the presence of heparin-like anticoagulant (5-11), which is also observed in solid tumors $(12,13)$, chronic renal disease and other hematological malignancies such as chronic lymphocytic leukemia and $\mathrm{T}$ cell lymphoma $(14,15)$. In the present report, the specific case of a middle-aged male diagnosis with a rare type of MM which is IgD lambda light chain and lambda light chain, presenting obvious abnormal coagulation profiles which showed the presence of heparin-like anticoagulant, was treated with chemotherapy and then the coagulation functions were corrected. We present the following case in accordance with the CARE reporting checklist (16) (available at http://dx.doi.org/10.21037/tcr-20-1968).

\section{Case presentation}

A 48-year-old man was admitted to the first affiliated 


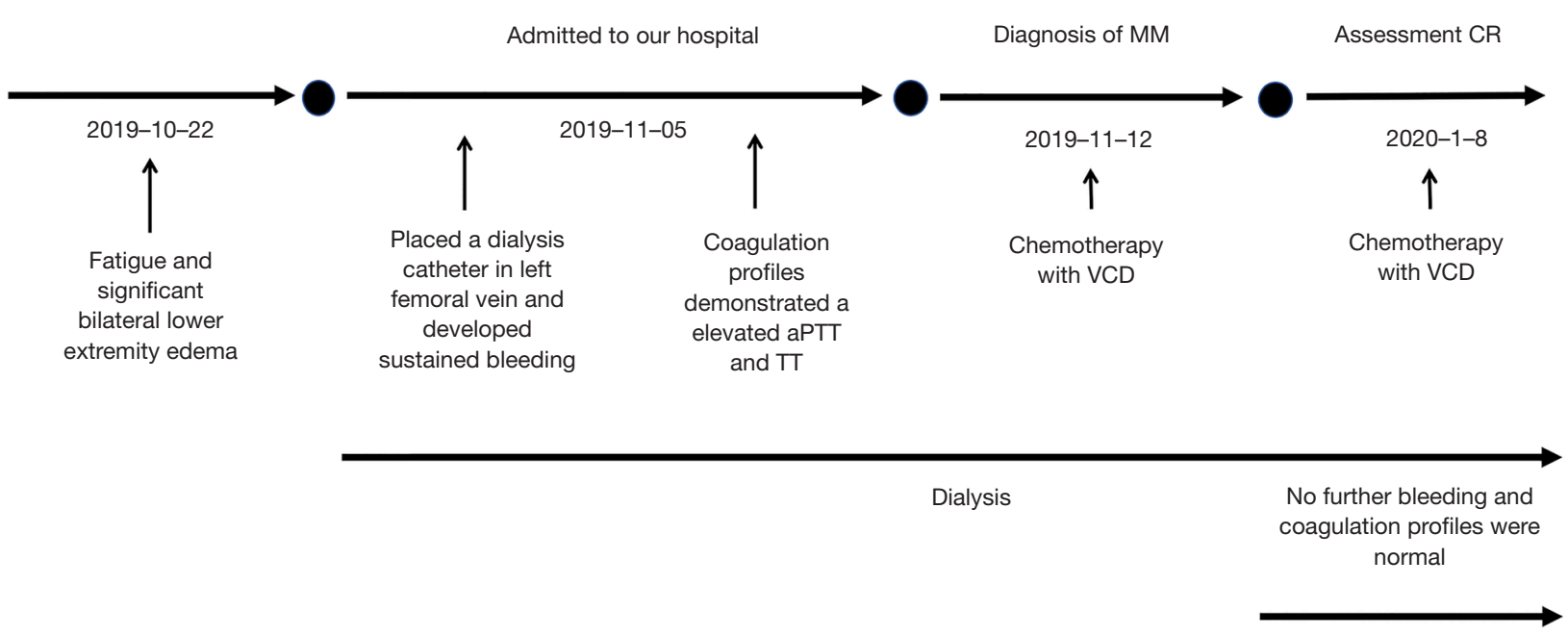

Figure 1 A timeline of the multiple myeloma case. aPTT, activated partial thromboplastin time; TT, thrombin time; MM, multiple myeloma; VCD, bortezomib combined with cyclophosphamide and dexamethasone; CR, complete remission.

hospital of Nanjing Medical University, Jiangsu Province Hospital on November 2019 because of fatigue and significant bilateral lower extremity edema on physical examination. Throughout the duration of symptoms, the patient did not have hematuria, epistaxis, hematochezia, oral ulcers, skin lesions or arthralgia. The patient had no medical history, bleeding history or family history of bleeding. The timeline of this patient is shown in Figure 1. All procedures performed in studies involving human participants were in accordance with the ethical standards of the Ethics Committee of Jiangsu Province Hospital and with the Helsinki Declaration (as revised in 2013). Written informed consent was obtained from the patient.

Laboratory studies revealed an elevated white blood count of $24.44 \times 10^{9} / \mathrm{L}$, elevated platelet count of $339 \times 10^{9} / \mathrm{L}$, decreased hemoglobin of $63 \mathrm{~g} / \mathrm{L}$, while percentage of reticulocytes was $6.60 \%$. Total serum protein was $61.3 \mathrm{~g} / \mathrm{L}(65-85 \mathrm{~g} / \mathrm{L})$ with $28.7 \mathrm{~g} / \mathrm{L}$ $(40-55 \mathrm{~g} / \mathrm{L})$ albumin and $32.6 \mathrm{~g} / \mathrm{L}(20-40 \mathrm{~g} / \mathrm{L})$ globulin, calcium of $2.12 \mathrm{mmol} / \mathrm{L}(2.2-2.65 \mathrm{mmol} / \mathrm{L})$, and creatinine of $936.2 \mathrm{mmol} / \mathrm{L}(44-133 \mathrm{mmol} / \mathrm{L})$. The level of $\operatorname{IgG}, \operatorname{IgA}, \operatorname{IgM}$ and $\operatorname{IgD}$ were $1.61 \mathrm{~g} / \mathrm{L},<0.24 \mathrm{~g} / \mathrm{L}$, $<0.175 \mathrm{~g} / \mathrm{L}$ and $4.42 \mathrm{~g} / \mathrm{L}$ respectively. The serum free light-chain (FLC) of kappa was $17.6 \mathrm{mg} / \mathrm{L}$ and lambda was $2,400 \mathrm{mg} / \mathrm{L}$, the ratio of kappa/lambda was 0.007 . Serum protein electrophoresis (SPEP) showed a $M$ protein of $9.9 \%$ and serum immunofixation electrophoresis (SIFE) revealed two oligoclonal bands, IgD lambda light chain and lambda light chain. The 24-hour urine for total protein was $11.1 \mathrm{~g}$ and the urine immunofixation electrophoresis (UIFE) showed a monoclonal of lambda light chain. Serum beta2 microglobulin was $27.1 \mathrm{mg} / \mathrm{L}$ and $\mathrm{LDH}$ was $262 \mathrm{U} / \mathrm{L}$ (140-271 U/L). The bone marrow smear showed primary plasma cells account for $30.4 \%$ and flow cytometry revealed an abnormal plasma cell population, expressing CD38, CD138, CD56 and lambda light chains. Hematopathology revealed extensive bone marrow involvement (40\%) by plasma cells. Chromosome was normal and the Fluorescence in situ hybridization (FISH) of MM was negative. So patient was diagnosed with multiple myeloma (IgD lambda + lambda, ISS III, R-ISS II).

Notably, because of acute renal insufficiency, a dialysis catheter was placed in the left femoral vein. The patient developed sustained bleeding at the site of puncture. The coagulation profiles demonstrated that mildly elevated prothrombin time (PT) at $14 \mathrm{~s}$ (normal range 8.0-14.0 s) and a significantly elevated activated partial thromboplastin time (aPTT) at $117.9 \mathrm{~s}(25.0-31.3 \mathrm{~s})$ and thrombin time (TT) at $28.5 \mathrm{~s}(15-21 \mathrm{~s})$, while the reptilase time (RT) was normal. Addition of an equal volume of normal plasma did not correct the aPTT completely. The level of coagulation factors was listed in Table 1. The test of lupus anticoagulant, antiphospholipid syndrome, antinuclear antibodies and antineutrophil cytoplasmic antibodies were normal. The prolonged TT ( $31.9 \mathrm{~s})$ was corrected to $16.2 \mathrm{~s}$ with in vitro addition of $100 \mu \mathrm{g}(5 \mu \mathrm{g} / \mu \mathrm{L})$ protamine sulfate, which indicated the presence of a heparin-like anticoagulant. 
Table 1 Activity of coagulation factors

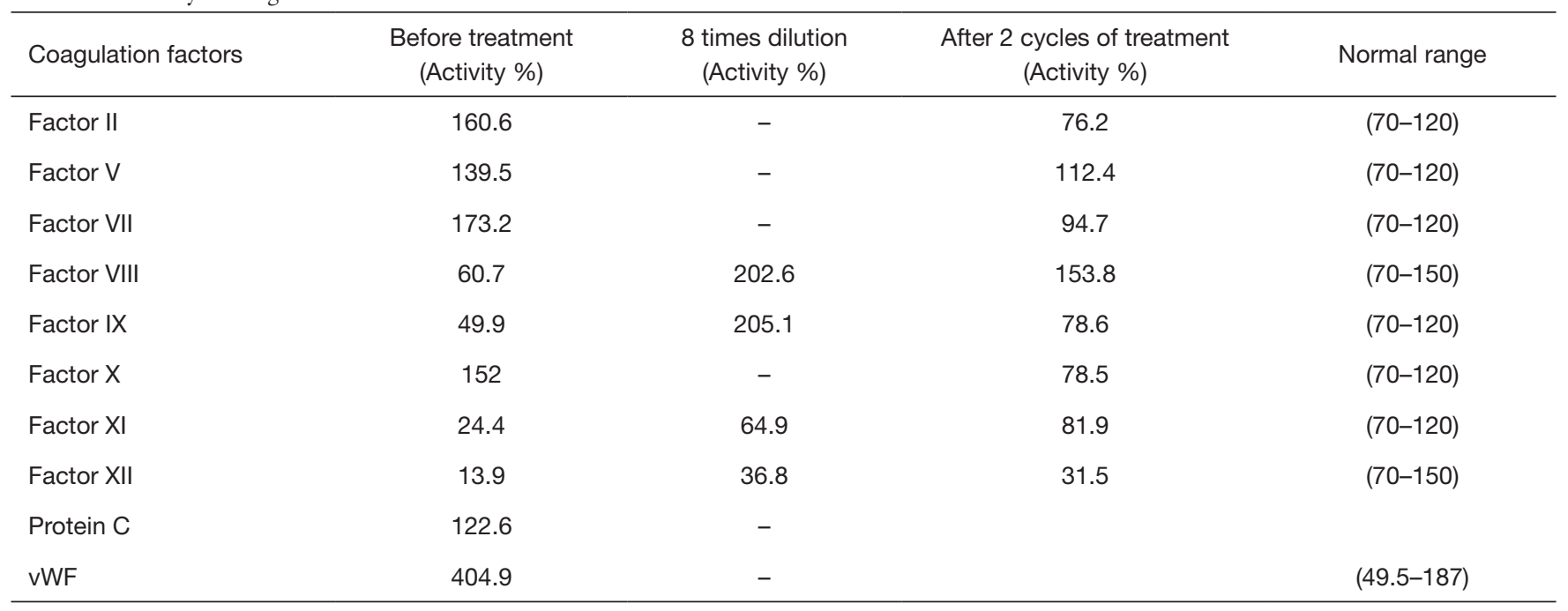

vWF, von Willebrand factor.
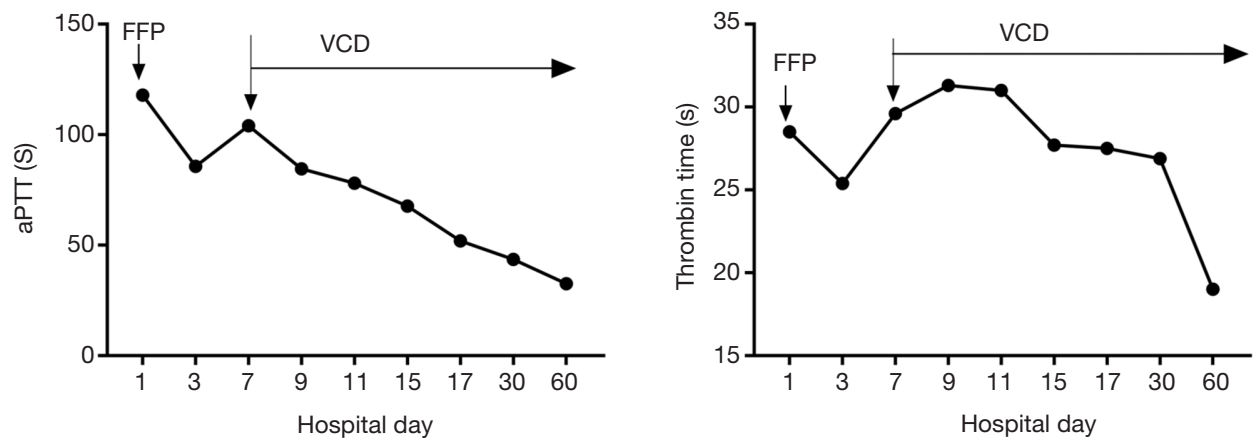

Figure 2 The aPTT and thrombin time (TT) were not corrected by infusion of fresh-frozen plasma (FFP). After treatment of VCD (bortezomib cyclophosphamide, dexamethasone) both aPTT and TT were shortened gradually and drop back to normal level after 2 cycles of bortezomib combined with cyclophosphamide and dexamethasone (VCD).

No heparin or other anti-coagulants were administered at any time. The infusion of fresh-frozen plasma had no significant effect on the coagulation studies or the bleeding time. After treatment of 2 cycles of bortezomib $\left(1.3 \mathrm{mg} / \mathrm{m}^{2}\right.$, day $\left.1,4,8,11\right)$ combined with cyclophosphamide (CTX) $\left(300 \mathrm{mg} / \mathrm{m}^{2}\right.$, day $\left.1,8,15\right)$ and dexamethasone (Dex) (20 mg, day 1-2, 4-5, 8-9, 11-12) therapy, the SPEP, SIFE and UIFE were negative and FLC was normal, meanwhile the patient did not show any other signs of bleeding and the aPTT and TT were back to normal (Figure 2). The patient showed no adverse and unanticipated events as of the last follow- up on January 2020 (Figure 1).

\section{Discussion}

Our patient was diagnosed with $M M$ and presented with sustained bleeding at the puncture site. The coagulation profile is remarkable for prolonged aPTT and TT, while mixing test could not correct the aPTT. This suggested the presence of inhibitor of coagulation factors or lupus anticoagulant. The test of coagulation factors showed low activity of factor VIII, factor IX, factor XI and factor XII. However, the fact that the activities of these coagulant factors elevated after 8 times dilution of the plasma demonstrated that no specific inhibitors of these coagulation factors existed. Meantime the lupus 
Table 2 Coagulation abnormalities in multiple myeloma patients derived from the summary of case reports

\begin{tabular}{|c|c|c|c|c|c|c|c|c|c|c|c|c|c|}
\hline No. & Age & Gender & Diagnosis & $\mathrm{PT}(\mathrm{s})$ & aPTT (s) & $\mathrm{TT}(\mathrm{s})$ & $\mathrm{RT}$ (s) & Fbg (g/L) & $\begin{array}{l}\text { Subtypes } \\
\text { of myeloma }\end{array}$ & $\begin{array}{l}\text { At the } \\
\text { time of } \\
\text { diagnosis }\end{array}$ & Treatment & Prognosis & Article \\
\hline 3 & 47 & Male & MM & 25 & 44 & $>600$ & 17 & 432 & IgG lambda & Yes & $\begin{array}{l}\text { L-phenylalanine } \\
\text { mustard + } \\
\text { prednisone }\end{array}$ & $\begin{array}{l}\text { Dead } \\
\text { of renal } \\
\text { failure and } \\
\text { coronary } \\
\text { artery } \\
\text { disease }\end{array}$ & \\
\hline 5 & - & - & MM & 15 & 35.4 & 122 & 22 & - & $\lg G+\lg A$ & Yes & Protamine & Unknown & $\begin{array}{l}\text { Bayer- } \\
\text { Garner } \\
2001(11)\end{array}$ \\
\hline 6 & 55 & Male & MM & 14 & 63 & 65 & 22 & 267 & IgG lambda & No & $\begin{array}{l}\text { Chemotherapy + } \\
\text { ASCT }\end{array}$ & Unknown & $\begin{array}{l}\text { Torjemane } \\
2007 \text { (5) }\end{array}$ \\
\hline 7 & 73 & Female & MM & - & - & - & - & - & $\lg G$ & Yes & $\begin{array}{l}\text { Recombinant } \\
\text { FVIla }+ \\
\text { chemotherapy }\end{array}$ & $\begin{array}{l}\text { PR and } \\
\text { no further } \\
\text { bleeding } \\
\text { events }\end{array}$ & $\begin{array}{l}\text { Martínez- } \\
\text { Martínez } \\
2016(9)\end{array}$ \\
\hline
\end{tabular}

PT, prothrombin time; aPTT, activated partial thromboplastin time; TT, thrombin time; RT, reptilase time; Fbg, fibrinogen; MM, multiple myeloma; MGUS, monoclonal gammopathy of undetermined significance.

anticoagulant was negative. The TT was corrected by the addition of protamine sulfate, which suggested a heparinlike anticoagulant.

Several MM patients were reported to have heparinlike anticoagulants with mild to severe hemorrhage (Table 2). The source of acquired heparin-like anticoagulants is poorly understood. Some authors believe that these substances are derived from myeloma cells. Lamia Torjemane et al. considered that soluble CD138 may play a role in generating heparin-like anticoagulants (5), but there is no clear evidence to support this view. MartínezMartínez et al. found that IgG could act as heparin binding the heparin binding domain of antithrombin which may contribute to the risk of bleeding of MM patients (9).
We started chemotherapy (bortezomib combined with cyclophosphamide and dexamethasone) on the patient after he was diagnosis with MM. The normalization of TT with the reduction of the tumor burden may support this hypothesis. Of note, in the case reported by MartínezMartínez et al., the patient had an IgG-gamma myeloma, while our patient had an IgD lambda + lambda, which is a rare type of MM.

It is worth noting that not all patients had abnormal coagulation at the time of diagnosis. Some patients acquired heparin-like anticoagulants after the treatment, while their MM was in remission. And some primary amyloid patients without detectable serum M-proteins also had prolonged TT, suggesting that the heparin-like anticoagulants may not 
derived from $M$-proteins $(17,18)$.

There is a lack of literature on treatment of MM patients with acquired heparin-like anticoagulants. According to existent literature, the choice of treatment is mainly based on the degree of bleeding. Patients with severe, life-threatening bleeding may benefit from infusing with protamine sulfate which can neutralize the heparinlike anticoagulants $(5,6)$, while no guidelines on dosing is established yet. Plasmapheresis may also be effective in some cases (19). For our patient who had non-lifethreatening bleeding, chemotherapy for MM did correct the prolonged TT and stopped the bleeding.

No association has been drew between the existence of heparin-like anticoagulants and poorer prognosis among MM patients. This also supports that the heparin-like anticoagulants may not be exclusively secreted by myeloma cells. According to the report of Tefferi et al., their patients all died of bleeding or sepsis, rather than the primary disease.

In our case, this patient is diagnosed with $\mathrm{MM}$ of $\operatorname{IgD}$ lambda light chain and lambda light chain, which is a rare type of MM, and no heparin-like anticoagulants has been reported in patients with this type of MM. It is a pity that we did not extract M-protein from patient's peripheral blood for further verification, so we cannot directly prove that the source of the heparin-like anticoagulant is the $M$ protein. Chemotherapy can clear the $M$ protein, but the effect on heparin-like anticoagulants needs further study.

In summary, heparin-like anticoagulants are uncommon in MM patients, and bleeding may fatal, early evaluation of the coagulation function of MM patients is clinically important for early intervention. In order to better understand the origin and roles of these anticoagulants, future research are warranted.

\section{Acknowledgments}

We thank all members of our group for their efforts and enthusiasm.

Funding: None.

\section{Footnote}

Reporting Checklist: The authors have completed the CARE reporting checklist. Available at http://dx.doi.org/10.21037/ tcr-20-1968

Conflicts of Interest: All authors have completed the ICMJE uniform disclosure form (available at http://dx.doi. org/10.21037/tcr-20-1968). The authors have no conflicts of interest to declare.

Ethical Statement: The authors are accountable for all aspects of the work in ensuring that questions related to the accuracy or integrity of any part of the work are appropriately investigated and resolved. All procedures performed in studies involving human participants were in accordance with the ethical standards of the Ethics Committee of Jiangsu Province Hospital and with the Helsinki Declaration (as revised in 2013). Written informed consent was obtained from the patient.

Open Access Statement: This is an Open Access article distributed in accordance with the Creative Commons Attribution-NonCommercial-NoDerivs 4.0 International License (CC BY-NC-ND 4.0), which permits the noncommercial replication and distribution of the article with the strict proviso that no changes or edits are made and the original work is properly cited (including links to both the formal publication through the relevant DOI and the license). See: https://creativecommons.org/licenses/by-nc-nd/4.0/.

\section{References}

1. Quek JK, Wong WH, Tan CW, et al. Acquired factor V deficiency in a patient with myeloma and amyloidosis. Thromb Res 2018;164:1-3.

2. Muzaffar J, Katragadda L, Haider S, et al. Rituximab and intravenous immunoglobulin (IVIG) for the management of acquired factor VIII inhibitor in multiple myeloma: case report and review of literature. Int J Hematol 2012;95:102-6.

3. Shinagawa A, Kojima H, Kobayashi T, et al. Lupus anticoagulant-like activity observed in a dimeric lambda protein produced by myeloma cells. Int J Hematol 2001;73:526-31.

4. Post GR, James L, Alapat D, et al. A case of acquired dysfibrinogenemia in multiple myeloma treated with therapeutic plasma exchange. Transfus Apher Sci 2013;48:35-8.

5. Torjemane L, Guermazi S, Ladeb S, et al. Heparinlike anticoagulant associated with multiple myeloma and neutralized with protamine sulfate. Blood Coagul Fibrinolysis 2007;18:279-81.

6. Tefferi A, Nichols WL, Bowie EJ. Circulating heparinlike anticoagulants: report of five consecutive cases and a 
review. Am J Med 1990;88:184-8.

7. Chapman GS, George CB, Danley DL. Heparin-like anticoagulant associated with plasma cell myeloma. Am J Clin Pathol 1985;83:764-6.

8. Willner CA, Chisti MM. Treatment of Bleeding Diathesis Associated with a Heparin-Like Anticoagulant in Plasma Cell Neoplasia Using Protamine. Case Rep Hematol 2018;2018:4342301.

9. Martínez-Martínez I, González-Porras JR, Cebeira MJ, et al. Identification of a new potential mechanism responsible for severe bleeding in myeloma: immunoglobulins bind the heparin binding domain of antithrombin activating this endogenous anticoagulant. Haematologica 2016;101:e423-e426.

10. Palmer RN, Rick ME, Rick PD, et al. Circulating heparan sulfate anticoagulant in a patient with a fatal bleeding disorder. N Engl J Med 1984;310:1696-9.

11. Bayer-Garner IB, Sanderson RD and Dhodapkar MV, et al. Syndecan-1 (CD138) Immunoreactivity in Bone Marrow Biopsies of Multiple Myeloma: Shed Syndecan-1 Accumulates in Fibrotic Regions. Mod Pathol 2001;14:1052-8.

12. Rodgers GM, Corash L. Acquired heparinlike anticoagulant in a patient with metastatic breast carcinoma.
West J Med 1985;143:672.

13. Wages DS, Staprans I, Hambleton J, et al. Structural characterization and functional effects of a circulating heparan sulfate in a patient with hepatocellular carcinoma. Am J Hematol 1998;58:285-92.

14. Cetingil AI, Ulutin ON, Karaca M. Heparin-like Anticoagulant Occuring in Association with Chronic Nephritis. Br Med J 1959;2:38-9.

15. Llamas P, Outeirino J, Espinoza J, et al. Report of three cases of circulating heparin-like anticoagulants. Am J Hematol 2001;67:256-8.

16. Riley DS, Barber MS, Kienle GS, et al. CARE 2013 Explanations and Elaborations: Reporting Guidelines for Case Reports. J Clin Epidemiol 2017;89:218-35.

17. Gastineau DA, Gertz MA, Daniels TM, et al. Inhibitor of the thrombin time in systemic amyloidosis: a common coagulation abnormality. Blood 1991;77:2637-40.

18. Mumford AD, O'Donnell J, Gillmore JD, et al. Bleeding symptoms and coagulation abnormalities in 337 patients with AL-amyloidosis. Br J Haematol 2000;110:454-60.

19. Goddard IR, Stewart WK, Hodson BA, et al. Plasma exchange as a treatment for endogenous glycosaminoglycan anticoagulant induced haemorrhage in a patient with myeloma kidney. Nephron 1990;56:94-6.
Cite this article as: Shen $\mathrm{H}, \mathrm{Wu} \mathrm{C}$, Chen L, Zhang R. Acquired heparin-like anticoagulation process in a patient with multiple myeloma: a case report and literature review. Transl Cancer Res 2020;9(11):7366-7371. doi: 10.21037/tcr-20-1968 